\title{
Obituary: John Ballantyne CBE, FRCS, DLO, Hon FRCSI, Hon FRCPS Glas, Hon FCS(SA), Assistant JLO Editor 1973-1978, JLO Editor 1978-1988
}

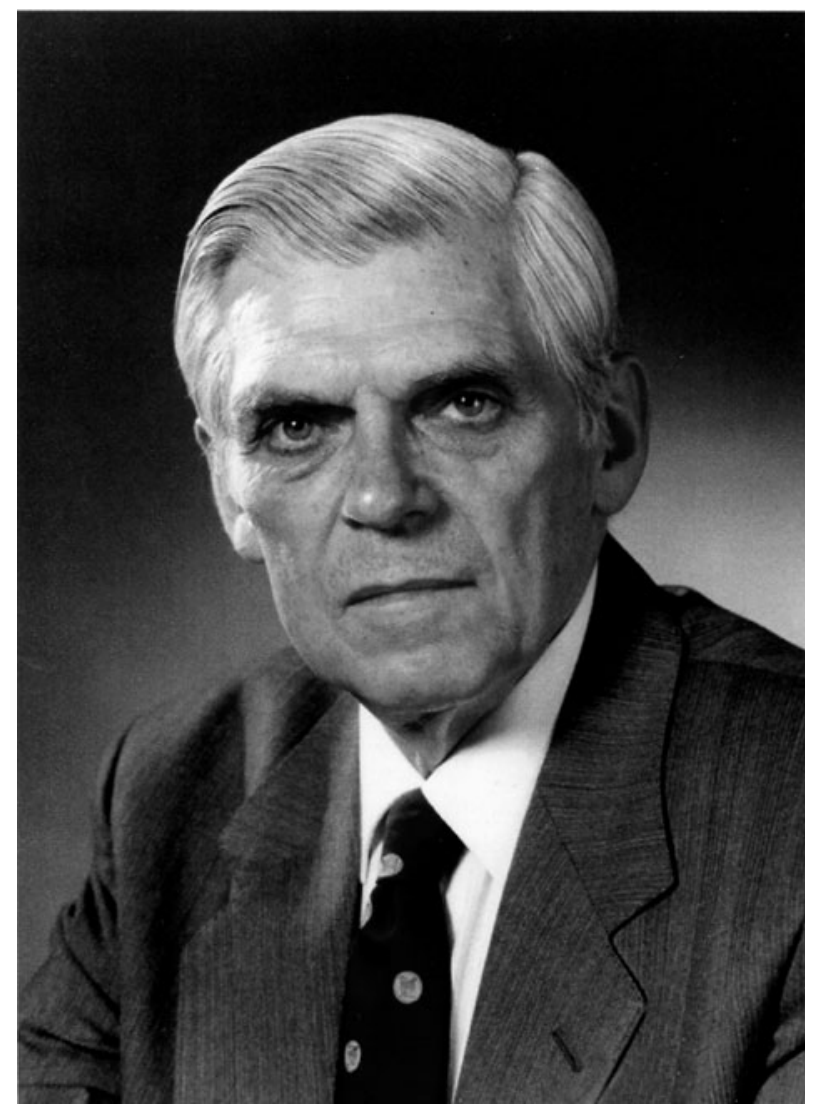

John Ballantyne, a genial, kindly, hard-working man, gave much to British and world otolaryngology. $\mathrm{He}$ was a champion of deaf people of all ages, a skilful and versatile surgeon, an author, editor, teacher, mentor, musician and above all a friend to otolaryngologists throughout the world.

The Journal of Laryngology \& Otology (JLO) remembers him as a distinguished editor whose skills benefited hundreds of authors. He was not blessed, as JLO editors are nowadays, with a team of subeditors, proofreaders and production editors. With the help of only his tireless secretary, he performed all these tasks himself, including handwriting letters to each author. He co-authored, with Professor Ted Evans and the late Mr Andrew Morrison, an influential report (published as the first JLO supplement in 1978) on cochlear implantation (CI), which paved the way for further work by the Medical Research Council and for the later adoption of CI by the Department of Health and Social Security. As Chairman of the Department of Health and
Social Security Advisory Committee On Services For Hearing Impaired People (1974-80), he introduced hearing therapists and contributed to the establishment of specialist audiological physicians.

John Chalmers Ballantyne was born during a Zeppelin raid on Nottingham on 26 September 1917 . He was a triplet - preceded by his sister Jeannie and followed by his identical twin brother, Rollo. His father was a Unitarian minister who soon moved on to a living in Merseyside. Their mother, Muriel, was ethereal, artistic and musical. All her children, including the triplets' older brother David, skilfully played the piano.

After happy school days in Liverpool, John and Rollo talked to their uncle Arthur Ballantyne (Professor of Ophthalmology in Glasgow) about becoming doctors and he recommended them to take First MB at St Mary's in London. This was during the deanship of Dr Charles Wilson (later Sir Charles and Lord Moran). He positively encouraged students to take the MB and must have welcomed the versatile Ballantyne twins. They enjoyed athletics and swimming and founded the St Mary's Music Society. They followed an accelerated course to enable them to qualify early, in 1942, in order to join the Services during the Second World War.

The Captains Ballantyne joined the Royal Army Medical Corps and were posted to Gibraltar. John was attached to the Royal Scots and began training as an otolaryngologist with $\mathrm{R}$ Scott Stevenson, whose interest in deafness and ease in writing left a marked impression. John's first paper to be published in the JLO was co-authored with his mentor, Scott Stevenson, and was entitled 'The conservative treatment of chronic suppurative otitis media'. After the war, he completed his army service in Hamburg and Oxford, before in 1947 becoming Registrar to Jack Angell-James in Bristol. During 1949-50, he combined the posts of Registrar to the Royal Cancer Hospital, London, with a Research Registrar post in the audiology unit at Golden Square Hospital, working with Edith Whetnall. This post stimulated John's interest in deafness and the structure and function of the inner ear. After three successful years as Senior Registrar to John Simpson and Ian Robin at St Mary's, he gained his first part-time consultant post at the Royal Northern Hospital (19531969). At the same time, he became Assistant Director to the Audiology Unit at the Royal National Throat, Nose and Ear Hospital and also Otologist to the London County Council. This experience led to the publication of his first book, Deafness, in 
1960. It was written to help parents of deaf children and the adult deaf, and has since been used by generations of audiologists in training. John's second daughter, Deborah, an audiological scientist, translated the book into Italian.

After five years at the Audiology Unit and the London County Council, John moved on to a consultant post at the Royal Free Hospital. His senior colleague, Bill Scott-Brown, introduced him to private practice in Harley Street, and to his textbook Diseases of the Ear, Nose and Throat, first published in 1952. The two John's, John Ballantyne and John Groves, helped Scott-Brown with the second (1965), third (1971) and fourth (1979) editions, with each succeeding edition becoming a volume larger.

John Ballantyne edited the second and third editions of the Synopsis of Otolaryngology in 1967 and 1978 with his former chiefs from St Mary's. He edited both the ear volume and the nose and throat volume for the third edition of Rob and Smith's Operative Surgery in 1976, contributing chapters on stapedectomy and nasal surgery. In 1986, he repeated the exercise for the fourth edition, this time with $\mathrm{Mr}$ Andrew Morrison and Professor D F N Harrison as his co-editors of the ear and the nose and throat volumes, respectively.

Experience gained from a sabbatical with Professor Hans Engstrom resulted in the joint publication of a paper on the morphology of the 'vestibular ganglion cells'. This work stimulated Ballantyne's collaboration with the late Professor Imrich Friedmann (who was for many years the JLO's Advisor in Pathology) in co-editing a book in 1984 entitled Ultrastructural Atlas of the Inner Ear.

John Ballantyne was much in demand as a teacher, examiner and committee member. He never refused these duties, although in 1973 he is minuted as having seriously questioned the value of the repetitious work of the British Medical Association Otolaryngology Group; it ceased to function the same year. And yet, if he could help to lessen deafness, no task was too small. (He agreed, for example, to represent the British Medical Association Otolaryngology Group on a British Standards Committee studying noise from toys).

At the Royal Society of Medicine (RSM), John chose as the title of his 1976 Section of Otology Presidential Address 'The Hearing Ear; Variations on a Theme of Helmholtz', which enabled him to utilise his knowledge and love of music. He memorably played the passage in Smetana's first string quartet (from 'My Life') in which the composer described his own tinnitus.

During his time as Honorary Secretary of the British Association of Otolaryngologists (19721977), he also represented the Association on the Council of the Royal College of Surgeons. He examined for the FRCS in England and Ireland, and was Civilian Consultant in Otolaryngology to the Army.

For the British Academic Conference, he served as Honorary Secretary and later Chairman of the General Committee for the conferences in Edinburgh and London, respectively, and was invested as Master of the Seventh Conference in Glasgow in 1987. In the same year, he was elected an Honorary Fellow of the Royal College of Physicians and Surgeons of Glasgow.

John Ballantyne delivered the 16th James Yearsley Lecture in 1970 on the subject of ototoxicity, the Sir William Wilde Lecture in 1975 and the Toynbee Lecture in 1984. He was awarded the Harrison Prize in Otology (RSM) in 1971, and the Jobson Horne Prize (British Medical Association) in 1982, and was a member of the Collegium Oto-RhinoLaryngologicum Amicitiae Sacrum. For 20 years, he was a most supportive Director of the Britain Nepal Otology Service.

John Ballantyne was honoured with a CBE for services to the deaf in 1984, and received Honorary Fellowships of the Royal College of Surgeons in Ireland, the College of Surgeons of South Africa and the Royal Society of Medicine. In retirement, he was a founder member of the RSM's Retired Fellows' Society. The last meeting he was able to attend at the RSM was in December 2006, when, fittingly, he chaired a lecture given by his daughter, Jane. He for many years was administrator of the RSM Music Society, ending up as President. He never lost his youthful curiosity or humour, and was always reading, learning and wanting to know more.

While in Gibraltar in 1942 he met Barbara Green, a Wren from Bristol. They married in 1945 and she survives him with their two daughters, Jane, an Anaesthetist and Professor of Pain Control, University of Philadelphia, USA, and Deborah, Chief Audiological Scientist at 'La Sapienza' University in Rome, Italy.

John Ballantyne died on 25 June 2008, aged 90.

NeIL WeIR

ANDREW BROWN 